\title{
Synthesis of CMC from Palm Midrib Cellulose as Stabilizer and Thickening Agent in Food
}

\author{
FIRMAN SEBAYANG* and HELMINA SEMBIRING \\ Faculty of Mathematic and Natural Sciences, Chemistry Department, \\ University of Sumatera Utara Jalan Bioteknologi No. 01 Kampus USU Medan 20155 Indonesia. \\ *Corresponding author E-mail: sebayangkaro56@gmail.com \\ http://dx.doi.org/10.13005/ojc/330162
}

(Received: January 25, 2017; Accepted: February 14, 2017)

\begin{abstract}
The using of carboxymethyl cellulose (CMC) from palm midrib as stabilizer on ice-cream making is done in three steps. First step is isolation process of á-cellulose from palm midrib powder, FTIR analysis shows that the compound is a cellulose molecule. The second step is alkalization with isopropanol as the solvent, carboxymethylation with monochloroacetic acid, and neutralization with $\mathrm{CH}_{3} \mathrm{COOH} 90 \%$ then ethanol, methanol and aquadest are used for purification followed with centrifugation process and adding in acetone which gives carboxymethyl cellulose a positive result in qualitative analysis. FTIR peak obtained is similar to that of commercial CMC, with the degree of substitution 0.82 and viscosity $0.076 \mathrm{ml} / \mathrm{g}$. The last step is ice cream making process. In this step, $\mathrm{CMC}$ is added into the ice-cream batter with variated concentration of CMC starting from 0 to $0.5 \%$. Ice-cream produced is then given melting time test and the overrun value is determined. Based on the research, $0.5 \%$ addition of $\mathrm{CMC}$ shows the most optimum melting time which is 31.02 minutes and overrun value of $42.34 \%$. Organoleptic test given to 15 respondents also show that ice-cream with addition of $0.5 \% \mathrm{CMC}$ gives the best result for the soft texture, sweet taste, fragrance aroma and light brown colour. CMC for thickening agent in syrup is measured with Ostwald viscometer. It shows that syrup is thicker with the addition of $\mathrm{CMC}$. The highest vitamin- $\mathrm{C}$ content in passion fruit syrup is in addition of $0.3 \%$ which is 330.20 .
\end{abstract}

Keywords: Palm Oil Midrib, Cellulose, CMC, Stabilizer, Thickening Agent, Ice Cream, Syrup.

\section{INTRODUCTION}

Indonesia is the largest exporter of palm oil and its derivatives after Malaysia which is almost $32.64 \%$ of global export. North Sumatra is recorded to have 1.1 million hectares of palm oil plantation. The number reaches $24 \%$ of the total land in North
Sumatra, which is 72 thousand $\mathrm{km}$ square. From the total area known, it can be concluded that there is a lot of waste produced from the palm oil which are empty bunches, palm oil shell, midrib and etc. For instance in palm oil midrib, each year there are over 8.6 tonnes produced per hectare, and until today most of them are not being utilised. 
According to Padil and friends (2010), palm oil midrib has $34.89 \%$ of á-cellulose, $27.14 \%$ of hemicellulose and $19.87 \%$ of lignin. á-cellulose in palm oil midrib has a great potential to produce cellulose derivatives products.

With the lifestyle today, society demands food products not only to fulfil the quantity needed but also the quality. In order to increase the quality, food additives are therefore added in production. The most common additive used is carboxymethyl cellulose, as known as CMC.

A cellulose derivative known as $\mathrm{CMC}$ is commonly used in food industry to give better texture of food. For example, in ice-cream making, the uses of $\mathrm{CMC}$ enhances the texture and crystal lactose produced is softer. CMC is also often used in food to prevent retrogradation (Winarno, 1995).

Ice-cream is usually consumed as dessert and snacks. The principle of ice-cream making is to form air cavity or Ice Cream Mix (ICM) hence there will be increase in volume making the ice-cream lighter, fluffier and has soft texture (Padaga,M,dkk,2005).

Sundari and Saati (2009) have conducted research about the making of Aloe Vera (Aloe Chinensis) Ice-cream with addition of Gelling Agents. The best ice-cream was produced by the addition of $\mathrm{CMC}$ as a stabilizer with $0.5 \%$ concentration.

Cahyana and Saidi (2014) have analysed the effect of the types and concentration of stabilizer towards physical, chemistry and organoleptic characteristic in bran ice-cream. The combination of Na-CMS and carrageenan of $0.5 \%$ concentration gives the best physical and chemical variable and with carrageenan of $0.35 \%$ gives the best organoleptic characteristic.

Widiantoko and Yunianta (2014) have conducted research in Tempe-Ginger ice-cream (the study of the effect of ingredients and stabilizer proportion to physical, chemical and organoleptic properties). The best ice-cream was obtained from ratio tempe essence:ginger of 9:1 and addition of $0.25 \% \mathrm{CMC}$ for physical and chemical characteristic also ratio of $7: 3$ with addition of $\mathrm{CMC} 0.25 \%$ is the best for organoleptic properties.
Besides as a stabilizer, CMS is also used as a thickening agent, such as syrup. The regulation is to only use $1-2 \%$ of it in the product. Passion fruit is widely used as flavouring in processed beverages product like syrup. Passion fruit syrup is rich in vitamin-C. Vitamin-C is also called ascorbic acid, is a substance that easily get wet with water, have acid characteristic and as a reducing agent. Ascorbic acid is sensitive towards external influence that can break it such as temperature, sugar and salt concentration, $\mathrm{pH}$, oxygen enzyme and metal catalysator.

Based on the background mentioned, researcher is interested to conduct a research in the ice-cream making using $\mathrm{CMC}$ stabilizer with varied concentration of $0.1 ; 0.2 ; 0.3 ; 0.4$ and $0.5 \%$. Because in the previous research, it was only used three variations which are $0.2 ; 0.35$; and $0.5 \%$ therefore researchers are intrigued to know the effect of CMC stabilizer concentration towards physical and organoleptic properties from ice-cream obtained, also the use of CMC as thickening agent in passion fruit syrup with CMC variation of $1 \%, 2 \%$ and $3 \%$.

\section{METHODOLOGY}

\section{Equipment}

The equipment used in the research is analytical scale, 80 mesh sieve, hotplate stirrer, magnetic bar, thermometer, blender, oven, aluminium foill, funnel, centrifuge $4000 \mathrm{rpm}$, burette, Ostwald viscometer, desiccator, FTIR instrument, mixer, refrigerator, stopwatch.

\section{Material}

The materials used in the research are palm oil midrib, passion fruit, $\mathrm{NaOH}$ pellet, $\mathrm{NaOCl}_{(\mathrm{c})} 12 \%, \mathrm{CH}_{3} \mathrm{COOH}$ glacial, $\mathrm{H}_{2} \mathrm{O}_{2(\mathrm{c})} 30 \%$, Isopropanol, Monochloro acetate, standard cellulose, standard CMC, acetone, $\mathrm{CuSO}_{4} .5 \mathrm{H}_{2} \mathrm{O}_{(\mathrm{s})}, 1$-naphthol, methanol, ethanol, $\mathrm{PP}$ indicator, $\mathrm{HCl}_{(\mathrm{c})} 37 \%, \mathrm{HNO}_{3(\mathrm{c})}$ $65 \%, \mathrm{H}_{2} \mathrm{SO}_{4(\mathrm{c})} 98 \%, \mathrm{NaCl}_{(\mathrm{s})}$, full cream milk powder, Whipped cream, Dark chocolate, vanilla essence, yolk, granulated sugar.

\section{Procedurals}

\section{$\alpha$-Cellulose Isolation from Palm Oil Midrib}

As much as $75 \mathrm{~g}$ of palm oil midrib is put into a beaker glass, then add in $1 \mathrm{~L}$ of $\mathrm{NaOH} 2 \%$. Heat it at $100^{\circ} \mathrm{C}$ for 4 hours with constant stirring on a 
hotplate. Filter and washed precipitate obtained until the filtrate is in neutral $\mathrm{pH}$. Next it is bleached with $1 \mathrm{~L}$ of acetate buffer and $\mathrm{NaOCl} 1.7 \%$ with $1: 1$ ratio, heat it at $80^{\circ} \mathrm{C}$ for 6 hours with constant stirring on a hotplate. Then precipitate is collected and washed until neutral $\mathrm{pH}$ filtrate is obtained (Silverio et al. 2013).

Next add in $500 \mathrm{~mL}$ of $\mathrm{NaOH} 17.5 \%$ and heat it at $80^{\circ} \mathrm{C}$ for 30 minutes with constant stirring on a hotplate. Precipitate is collected again and washed until the filtrate is in neutral $\mathrm{pH} . \mathrm{H}_{2} \mathrm{O}_{2} 10 \%$ is then added and followed by heating up at $60^{\circ} \mathrm{C}$ for 15 minutes with constant stirring on a hotplate. Filtrate is discarded and precipitate is dried in an oven at $60^{\circ} \mathrm{C}$ and stored in a desiccator (Ohwoavworhua, 2005).

\section{The Making of Carboxymethyl Cellulose (CMC)}

As much as $5 \mathrm{~g}$ of á-cellulose powder is put into a beaker glass, then $150 \mathrm{~mL}$ isopropanol is added and stir. $15 \mathrm{~mL} \mathrm{NaOH} 25 \%$ is added and stir for 1 hour in room temperature. Next, $6 \mathrm{~g}$ of monochloro acetate is added and stir for 1.5 hours. Mixture is wrapped in aluminium foil and let dry in an oven at $60^{\circ} \mathrm{C}$ for 3.5 hours. After that mixture is immersed in $100 \mathrm{~mL}$ methanol for a night. It is then neutralise in $\mathrm{CH}_{3} \mathrm{COOH} 90 \%$ until ph 7 is reached, it is then filtered using a sintered funnel. Then it is washed three times by soaking it in $50 \mathrm{~mL}$ ethanol dor 10 minutes to remove dirt. Finally is it washed again with $100 \mathrm{ml}$ methanol absolute, filter and dry in an oven at $60^{\circ} \mathrm{C}$ for 4 hours. Then stored in a desiccator (Hong, 2013).

\section{Carboxymethyl Cellulose (CMC) Purification}

As much as $5 \mathrm{~g} \mathrm{CMC}$ is put into a beaker glass, then it is dissolve in $100 \mathrm{~mL}$ aquadest and heat on a hotplate at $80^{\circ} \mathrm{C}$ for 10 minutes and stir constantly. It is then centrifuge for 1 minutes in $4000 \mathrm{rpm}$, separating precipitate from its solution. Re-precipitated CMC is then dissolved in $100 \mathrm{~mL}$ acetone. It is then filtered, wrap in aluminium foil and dried in an oven at $60^{\circ} \mathrm{C}$ for 4 hours. Then stored in a desiccator. (Hong, 2013).

\section{Carboxymethyl Cellulose (CMC) Qualitative Analysis}

As much as $0.5 \mathrm{~g}$ of $\mathrm{CMC}$ is put into a beaker glass, then $50 \mathrm{~mL}$ aquadest is added. Heat it up at $60-70^{\circ} \mathrm{C}$ for 20 minutes with occasional stirring to homogenize the mixture. Cool it down and used it for test solution. It is divided to 3 reaction tubes.

Tube 1: put $5 \mathrm{~mL}$ test solution and $10 \mathrm{~mL}$ acetone. Shake gently and observe (give $(+)$ if white flocculant is formed).

Tube II: put $5 \mathrm{~mL}$ test solution and $5 \mathrm{~mL} \mathrm{\textrm {CuSO } _ { 4 }}$ $1.2 \mathrm{~N}$. Shake gently and observe (give (+) if light blue flocculant is formed).

Tube III: put $1 \mathrm{~mL}$ test solution, dilute it with $1 \mathrm{~mL}$ aquadest and add 5 drops of 1 -naphthol. Put tube in slope and give $2 \mathrm{~mL}$ of sulphuric acid then observe (give $(+)$ if a red purplish ring is formed) (COEI-1-CMC:2009).

\section{Determination of Degree of Substitution (DS)}

As much as $4 \mathrm{~g}$ of CMC dry powder is put into a beaker glass, the add $75 \mathrm{~mL}$ ethanol $95 \%$ and stir for 5 minutes. Then add in $5 \mathrm{~mL} \mathrm{HNO}_{3} 2 \mathrm{M}$ dan boil the mixture. Remove some of the liquid through heating on a hotplate for 10 minutes with constant stirring. Next separate mixture into 2 phases, solid and liquid phase. Liquid phase is discarded while the solid is washed with $20 \mathrm{ml} 60^{\circ} \mathrm{C}$ ethanol $80 \%$ for 5 times. Then precipitate is washed again with a little of anhydrous methanol, filter and dry in an over at $100^{\circ} \mathrm{C}$ for 3 hours. Cool it in a desiccator for $1 / 2$ hour. Then weigh $0.5 \mathrm{~g} \mathrm{CMC}$ and put it into a 250 $\mathrm{mL}$ erlenmeyer flask. Add in $100 \mathrm{~mL}$ aquadest and stir. Then add $25 \mathrm{~mL} \mathrm{NaOH} 0.3 \mathrm{M}$ and heat it until it boils for 15 minutes. Add in PP indicator and mixture is titrated with $\mathrm{HCl} 0.3 \mathrm{M}$ until there is a change in colour from light purple to colourless. Titration is repeated twice and count the average of $\mathrm{HCl}$ volume used (Hong, 2013)

Carboxymethyl $=\left(\left[\left(V_{0}-V n\right) M \times 0.059 \times 100\right]\right) / m$

Concentration (\%CM)

Degree of Substitution $=(162 \times \% \mathrm{CM}) /([5900-$ $(58 \times \% \mathrm{CM})])$

\section{Ice-Cream Production}

Mix dry material together ( $175 \mathrm{~g}$ granulated sugar, $250 \mathrm{~g}$ dark chocolate, $30 \mathrm{~g}$ chocolate powder, $1 / 2$ teaspoon vanilla essence) into the liquid mixture (600 mL whipped cream, $300 \mathrm{~mL}$ full cream milk) 
at $40^{\circ} \mathrm{C}$. Then put into different variation of stabilizer (CMC) and emulsifier material (6 egg yolks) and heat it until homogenous mixture is formed. It is pasteurised at $80^{\circ} \mathrm{C}$ for 25 seconds and stir. Cool it in room temperature. Homogenised in a mixer in warm temperature for 15 minutes. Store in refrigerator at $4^{\circ} \mathrm{C}$ for $4-12$ hours. Homogenised it back for 15 minutes. Then it is frozen in two stages, first stage at $-5^{\circ} \mathrm{C}$ until $-8^{\circ} \mathrm{C}$ and the second stage is at $-30^{\circ} \mathrm{C}$. Then every steps is given agitation process (stored again for 4 - 12 hours). Then store it back in the freezer (Padaga, M, dkk. 2005).

\section{Ice-Cream Endurance Test (Melting Time)}

Put $100 \mathrm{~g}$ ice-cream into a beaker glass in a room temperature. Then turn on a stopwatch and stop it when ice-cream melts and gives $100 \mathrm{~mL}$ liquid in a beaker glass. Then note down the time it takes when ice-cream melt.

\section{Passion Fruit Syrup Production}

$150 \mathrm{~g}$ passion fruit extract is put into a beaker glass then add $112.5 \mathrm{~g}$ granulated sugar then $1 \% \mathrm{CMC}$, heat the mixture on a hotplate at $100^{\circ} \mathrm{C}$ for 20 minutes with constant stirring and remove after syrup is thickened, then it is conducted vitamin- $C$ and viscosity tests towards the syrup produced.

\section{RESULTS AND DISCUSSION}

\section{Isolated á-Cellulose from Palm Oil Midrib}

With the process of delignification, bleaching, and purification in palm oil midrib sample will give white $\alpha$-cellulose. From 75 gram palm oil midrib powder will give 19.77 gram pure $\alpha$-cellulose (it is assumed to be $26.36 \%$ of the initial mass). The isolated $\alpha$-cellulose obtained can be seen in figure 1 and 2 .

\section{Carboxymethyl Cellulose (CMC) Production}

$\alpha$-cellulose obtained is then dealkylated with isopropanol and $\mathrm{NaOH} 25 \%$, de-carboxymethylated using monochloro acetate, neutralised with $\mathrm{CH}_{3} \mathrm{COOH}$ $90 \%$, purified by washing it with ethanol and methanol also with further purification by using centrifugation which will then produce white CMC powder. From 5 gram of $\alpha$-cellulose powder used, will give 5.96 gram CMC. Furthermore, the 5 gram CMC used will give 4.43 gram purer $\mathrm{CMC}$. The making of $\mathrm{CMC}$ before and after purification can be seen in figure 3 and 4 .

\section{Carboxymethyl Cellulose (CMC) Qualitative Analysis}

CMC produced is then analysed through qualitative analysis which is by adding other chemical resulting in desired changes according to available references. The reagents used are:

a. Acetone $=$ gives white flocculant

b. $\quad \mathrm{CuSO}_{4} 1.2 \mathrm{~N}=$ gives light blue flocculant

c. Aquadest $+1-\mathrm{Naphthol}+\mathrm{H}_{2} \mathrm{SO}_{4(\mathrm{c})}=$ gives a red purplish ring (COEI-1-CMC:2009).

They proved CMC produced gives positive results which can be seen in figure 5,6 and 7 below.

\section{Functional Group Analysis with FTIR Spectroscopy}

The analysis for $\alpha$-cellulose from palm oil midrib, commercial $\alpha$-cellulose, carboxymethyl cellulose from palm oil midrib, and carboxymethyl from commercial cellulose using FTIR spectroscopy can be seen in table 1 and figure 8 .

\section{Degree of Substitution Determination of Carboxymethyl Cellulose (CMC) \\ Potentiometric titration is used here to} determine the degree of substitution in this research. By using the equation in procedurals section to determine the degree of substitution, hence it gives the value for carboxymethyl content and its degree of substitution:

Given:

$\mathrm{V}_{1}=18.5 \mathrm{~mL}$

$\mathrm{V}_{2}=18.0 \mathrm{~mL} \quad \mathrm{~V}=18.5 \mathrm{~mL}$

$\mathrm{V}_{3}=19.0 \mathrm{~mL}$

Carboxymethyl Concentration $=([(25,03-18,5) \mathrm{x}$ $0,3 \times 0,059 \times 100]) / 0,5(\% \mathrm{CM})$

Carboxymethyl Concentration $(\% \mathrm{CM})=23.12$

Degree of Substitution $=(162 \times 23.12) /([5900$

- $(58 \times 20.886)])$

Degree of Substitution $=0.82$

Determination of Average Molecular Weight Viscosity of Carboxymethyl Cellulose (CMC)

Ostwald viscometer is used to determine the average molecular weight viscosity of carboxymethyl cellulose (CMC). It can be determined using the Mark and Houwink equation below: 
$[\eta]=\mathrm{K}\left[\mathrm{M} \_\mathrm{v}\right]^{\wedge} \alpha$

Description :

[ๆ] = Intrinsic viscosity

$\mathrm{M}_{\mathrm{v}} \quad=$ average molecular weight

$\mathrm{K} \quad=5.37 \times 10^{-4} \mathrm{ml} / \mathrm{g}$

$\alpha \quad=0.73$

Where the value for $\mathrm{K}$ dan $\alpha$ constant in the equation for CMC is already available based on existing reference (Eremeeva and Bykova, 1998). Table 2 below shows data of several velocity of CMC in Ostwald viscometer.

From table 2 above, relative, specific and reduction viscosity have to be determined. Thus they will give the average molecular weight by substituting intrinsic viscosity from a linear graphic from a ratio of CMC concentration used to reductive viscosity.

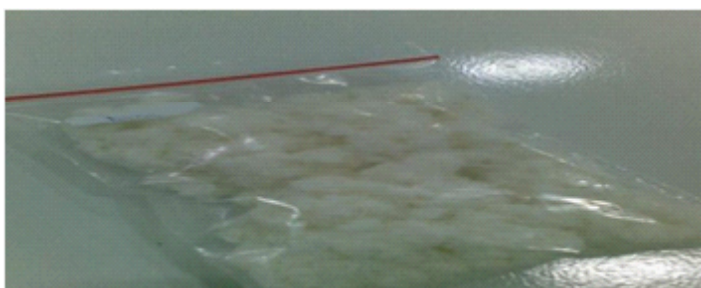

Fig. 1: $\alpha$-cellulose isolated from palm oil midrib

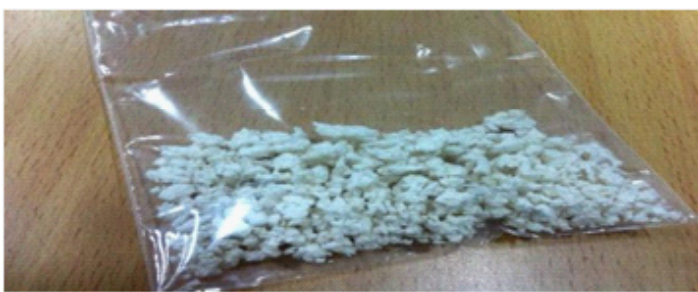

Fig. 3: CMC Before Purification
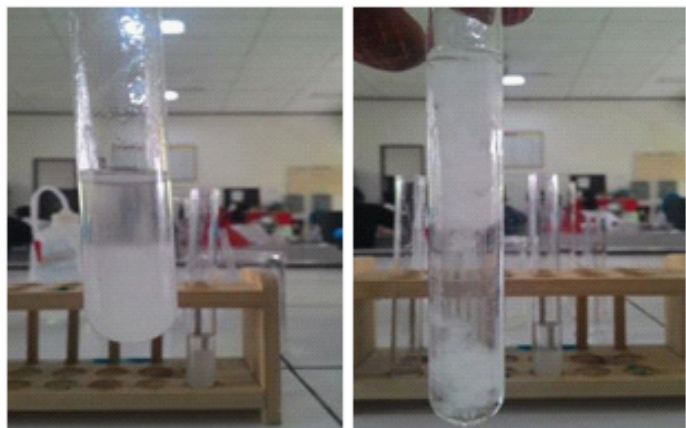

Fig. 5: CMC Qualitative Analysis with Acetone
Besides that $\mathrm{K}$ and á constant known also is substituted to get the average molecular weight. The equation used for relativem specific and reductive viscosity is below:

$$
\begin{aligned}
& \eta \_r=t \_n / t \_0 \\
& \eta \_s p=\left(t \_n-t \_0\right) / t \_0=\eta \_r-1 \\
& \eta \_r e d=\eta \_s p / C
\end{aligned}
$$

The equations above is one of the Huggins and Kramer equation (Hong, 2013). Based on the equation, the relative, specific and reductive viscosity can be seen in table 3 :

Through the data from table 3 above, therefore can be seen the intrinsic viscosity value

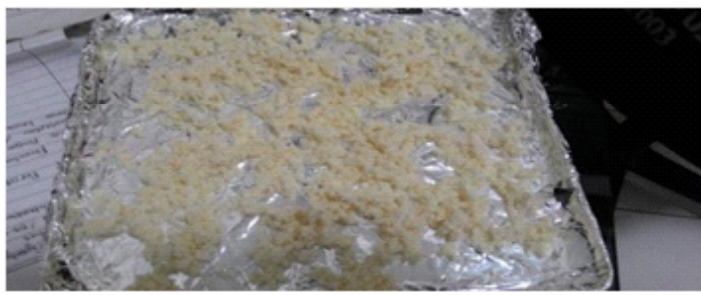

Fig. 2: Crushed $\alpha$-cellulose

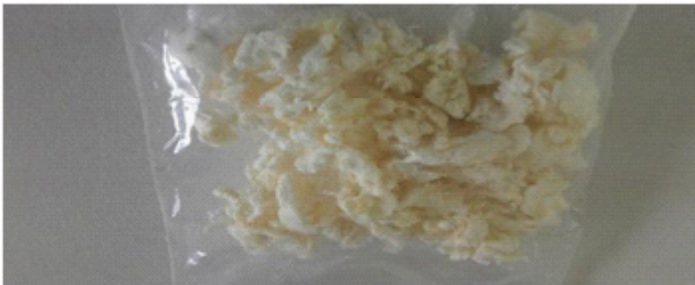

Fig. 4: CMC After Purification

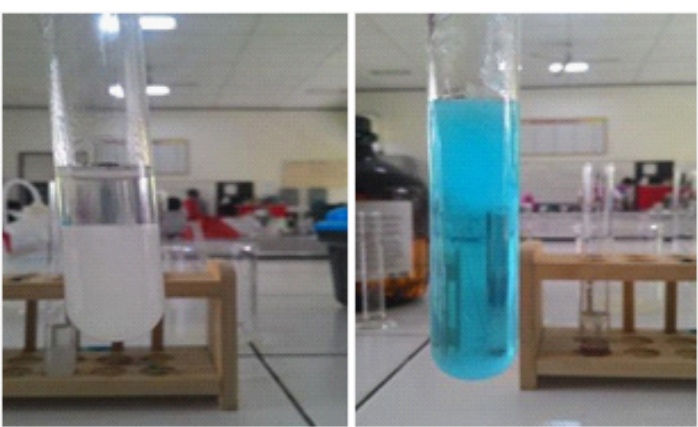

Fig. 6: CMC Qualitative Analysis with CuSO4 1.2N 
from linear graphic given the intercept from the plot is intrinsic viscosity value. From figure 9 can be seen that 0.076 intercept and viscosity of $0.076 \mathrm{ml} / \mathrm{g}$ are obtained:

Intrinsic volume [ $\eta$ ] above was obtained through several intercepts in the plot (in linear graphic) based on Huggin and Kramer equation:

$\eta \_$red $=\eta \_s p / C=[\eta]+k \_H[\eta]^{\wedge} 2 \mathrm{C}$

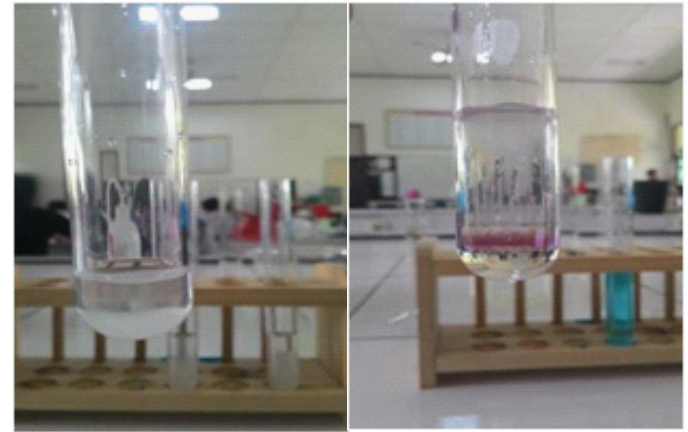

Fig. 7: CMC Qualitative Analysis with Aquadest + 1-Naphthol $+\mathrm{H}_{2} \mathrm{SO}_{4(\mathrm{c})}$
Therefore average molecular weight $\left(\mathrm{M}_{\mathrm{v}}\right)$ can be obtained from polymer, which is a polymer of carboxymethyl cellulose (CMC) based on intrisic viscosity value which is $0.076 \mathrm{ml} / \mathrm{g}$ through some calculations on equation 4.1.1 (attached) and average molecular weight $\left(M_{v}\right)$ obtained was $870.5625 \mathrm{~g} / \mathrm{mol}$.

\section{The Making of Ice-Cream}

The material used in making ice-cream in this research is milk. Other material includes milk. In this research, the making of ice-cream is done through varied $\mathrm{CMC}$ usage from $0.1 \%-0.5 \%$ also it is done the comparison between ice-cream with and without the addition of stabilizer. This is done in order to know the optimum $\mathrm{CMC}$ as stabilizer and its effect if added into ice-cream. Below is table 4 which will be shown from without any $\mathrm{CMC}$ and after $\mathrm{CMC}$ $0.1 \%-0.5 \%$.

In the making of the ice-cream two characteristics are observed, which are: organoleptic and physical quality. In this chapter 6 surveys in the research of ice-cream type is reported (organoleptic

Table 1: Wavelength of $\alpha$-cellulose from palm oil midrib, commercial á-cellulose, carboxymethyl cellulose from palm oil midrib, and carboxymethyl from commercial cellulose from FTIR Spectroscopy analysis

\begin{tabular}{|c|c|c|c|c|c|}
\hline \multicolumn{4}{|c|}{ Bulangan Gelombanz $\left(\mathrm{cm}^{-1}\right)$} & \multirow[b]{2}{*}{$\begin{array}{c}\text { Jeais } \\
\text { Vibrasi }\end{array}$} & \multirow[b]{2}{*}{$\begin{array}{l}\text { Gugus } \\
\text { Fungsi }\end{array}$} \\
\hline $\begin{array}{c}\text { a- } \\
\text { Selulosa } \\
\text { Pelepah } \\
\text { Kelapa } \\
\text { Sawit }\end{array}$ & $\begin{array}{l}\text { a-Selulosa } \\
\text { Komersil }\end{array}$ & $\begin{array}{c}\text { Karboksi- } \\
\text { metil } \\
\text { Selalosa } \\
\text { Pelepah } \\
\text { Kelapa } \\
\text { Sawit }\end{array}$ & $\begin{array}{c}\text { Karboksi- } \\
\text { metil } \\
\text { Selulosa } \\
\text { Komersil }\end{array}$ & & \\
\hline 3448 & 3348 & 3448 & 3425 & Soretchling & O.H \\
\hline 2893 & 2900 & 2900 & 2924 & Sorvetching & C.H \\
\hline - & - & 1604 & 1620 & Asmmeric & $\mathrm{COO}$ \\
\hline - & - & 1419 & 1427 & Bending & $\mathrm{CH}_{2}$ \\
\hline 1373 & 1319 & 1373,1319 & 1327 & Soresching & c.o \\
\hline 1056,1018 & 1056 & 1064,1026 & 1056,1018 & Symmety & c.o \\
\hline 894 & 902 & 894 & 902 & $\begin{array}{c}\beta- \\
\text { sobeoside } \\
\text { liskage }\end{array}$ & C.H \\
\hline
\end{tabular}




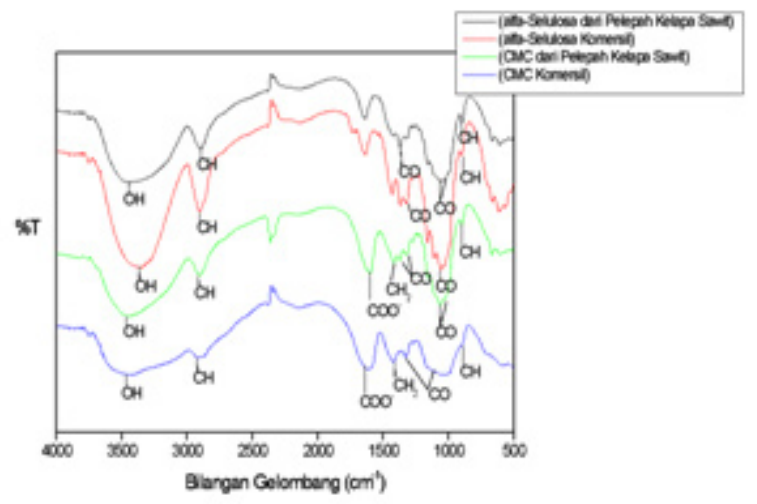

Fig. 8: FTIR Spectrum of $\alpha$-cellulose from $\alpha$-cellulose from palm oil midrib, commercial $\alpha$-cellulose, carboxymethyl cellulose from palm oil midrib, and carboxymethyl from commercial cellulose
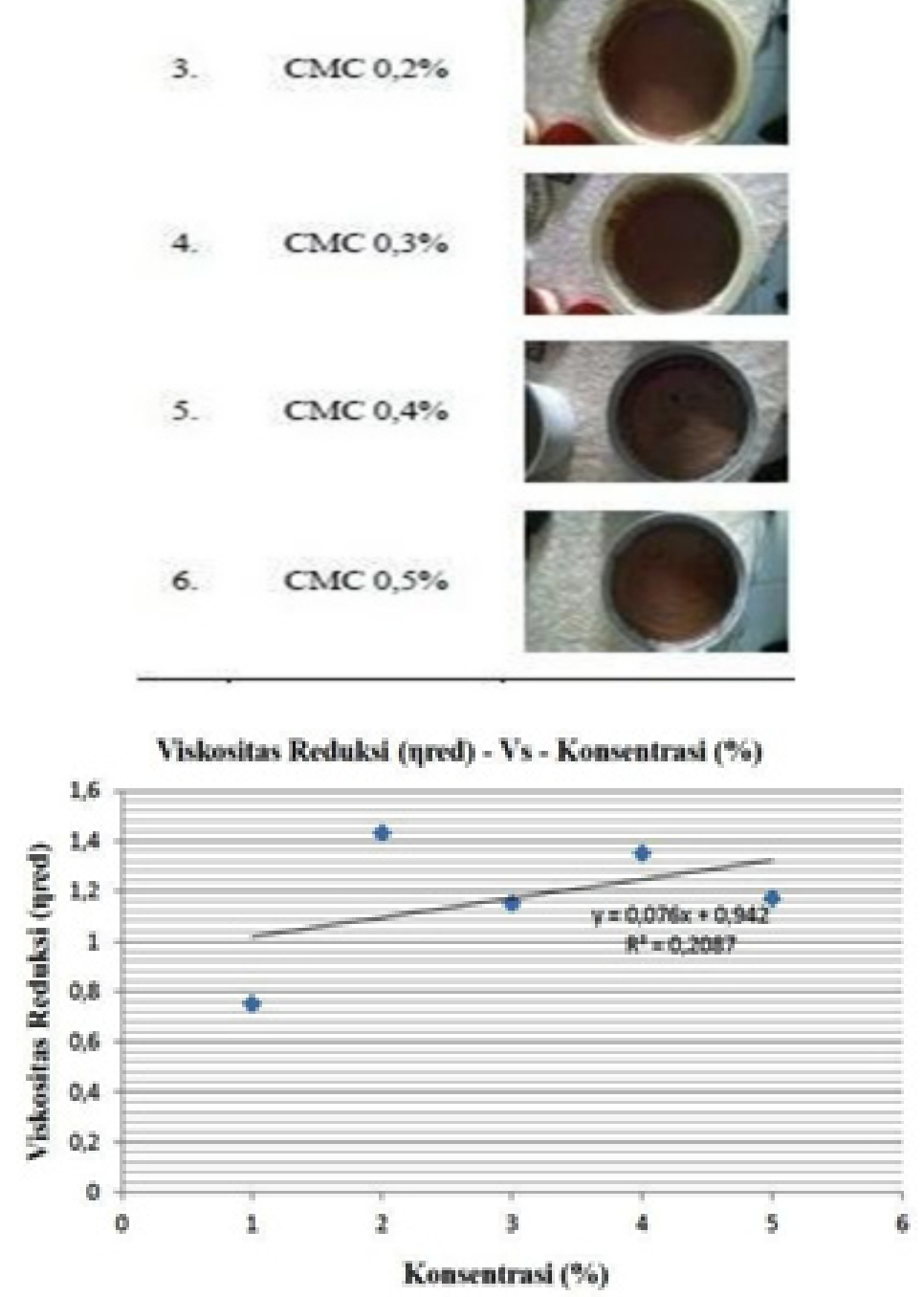

Fig. 9: Reductive Viscosity Graph to CMC concentration 
characterisation), while for physical quality is discussed in the next chapter which is about icecream endurance (melting Time).

Ice-cream survey in this research is given to 15 chemistry department students in University of Sumatera Utara whose age is not much differ (between 21 - 22 years old) to optimised organoleptic result in ice-cream produced. There are several observation done in the survey such as texture, flavour, aroma and colour. The description is as follow:

Table 2: The rate of flow of CMC in Ostwald Viscometer

\begin{tabular}{|c|c|c|c|c|}
\hline Larutan & $\begin{array}{c}\text { Waktu Laju } \\
\text { Alir } 1 \text { (detik) } \\
\left.\text { (t } t_{1}\right)\end{array}$ & $\begin{array}{c}\text { Wakfu L.aju } \\
\text { Alir } 2 \text { (detik) } \\
\text { (ty) }\end{array}$ & $\begin{array}{c}\text { Wakfu Laju } \\
\text { Alir } 3 \text { (detik) } \\
\text { (ts) }\end{array}$ & $\begin{array}{l}\text { Wakta Laju } \\
\text { Alir Rata - } \\
\text { Rata (detik) } \\
\text { (i) }\end{array}$ \\
\hline $\mathrm{NaCl}$ & 66.7 & 66.8 & 66.6 & 66.7 \\
\hline CMC $1 \%$ & 67,1 & 67,1 & 67.3 & 67,2 \\
\hline CMC $2 \%$ & 68,6 & 68,6 & 68,7 & 68.6 \\
\hline CMC $3 \%$ & 69 & 69 & 69 & 69 \\
\hline $\mathrm{CMK}_{4 \%}$ & 70.1 & 70.2 & 70.5 & 70.3 \\
\hline CMC $5 \%$ & 70,5 & 70,6 & 70,7 & 70.6 \\
\hline
\end{tabular}

Table 3: CMC data of relative, specific and reductive viscosity

\begin{tabular}{|c|c|c|c|}
\hline Konsentraxi (\%) & $\begin{array}{c}\text { Vhkositas Relatif } \\
\text { (サ) }\end{array}$ & $\begin{array}{c}\text { Visloositas } \\
\text { Spesifik (n-) }\end{array}$ & $\begin{array}{c}\text { Vikkonitas } \\
\text { Redulksi (nmes) }\end{array}$ \\
\hline$T$ & 1,0075 & 0.0075 & 0,75 \\
\hline 2 & 1.0285 & 0.0285 & 1.43 \\
\hline 3 & 1.0345 & 0.0345 & 1.15 \\
\hline 4 & 1,0540 & 0.0540 & 1,35 \\
\hline 5 & 1,0585 & 0.0585 & 1,17 \\
\hline
\end{tabular}

Table 4: Ice-cream without stabilizer and ice-cream with $\mathrm{CMC}$ as stabilizer of concentration from $0.1-0.5 \%$

\begin{tabular}{lll}
\hline No & Variasi & Gambar \\
1. & $\begin{array}{c}\text { Tanpa } \\
\text { Penambahan } \\
\text { CMC }\end{array}$ & \\
2. & $\mathrm{CMCO} 1 \%$ & \\
\hline
\end{tabular}

Texture: $A=$ Very soft,$B=$ Soft,$C=$ Rough, $D=$ Very rough

Flavour: $A=$ Very sweet, $B=$ Sweet,$C=$ Bitter, $D$ = Very bitter

Aroma : $\mathrm{A}=$ Fragrant, $\mathrm{B}=$ Less fragrant, $C=$ No fragrance

Colour: $\mathrm{A}=$ Light brown, $\mathrm{B}=$ Dark brown

Survey is conducted by giving 6 different types of ice-cream to participants who know that type 1 ice-cream is that without CMC, type 2 is ice-cream with $0.1 \% \mathrm{CMC}$ and so on with the $6^{\text {th }}$ ice-cream is ice-cream with $0.5 \%$ stabilizer. Then 
Tabel 5: Optimum Result from Ice-Cream Survey for Organoleptic Characters

\begin{tabular}{cccccc}
\hline \multirow{2}{*}{ Peserta } & Jenis Es Krim & \multicolumn{4}{c}{ Uji Oreanoleptik } \\
\cline { 3 - 6 } & yane Disukai & Tekstur & Rasa & Aroma & Warna \\
\hline 2 & 5 & B & A & C & A \\
3 & 5 & B & B & B & A \\
4 & S & B & B & A & A \\
5 & S & B & B & A & B \\
6 & 4 & B & B & B & A \\
7 & 2 & B & B & C & B \\
8 & 6 & A & B & B & B \\
9 & 1 & A & B & B & A \\
10 & 6 & A & A & B & A \\
11 & 6 & A & A & B & A \\
12 & 3 & B & B & B & B \\
13 & 6 & A & A & B & B \\
14 & 2 & B & B & A & A \\
15 & 6 & A & A & B & B \\
\hline
\end{tabular}

Table 6: Overrun Value of each Ice-Cream Variation

\begin{tabular}{cc}
\hline Jenis Es Krim & Nilai Overrun \\
\hline Tanpa Penambahan CMC & $12,2 \%$ \\
CMC 0,1\% & $17,3 \%$ \\
CMC 0,2\% & $20,26 \%$ \\
CMC 0,3\% & $26,13 \%$ \\
CMC 0,4\% & $33,97 \%$ \\
CMC $0,5 \%$ & $42,34 \%$ \\
\hline
\end{tabular}

Table 7: Ice-cream melting time

\begin{tabular}{cc}
\hline Jenis Es Krim & Waktu Pelelelaan (meait) \\
\hline Tanpa Penambahan CMC & 20.28 \\
CMC 0.196 & 22.29 \\
CMC 0.296 & 23.50 \\
CMC 0.396 & 25.20 \\
CMC 0.496 & 29.07 \\
CMC 0.596 & 31.02 \\
\hline
\end{tabular}


what is observed in the survey is which ice-cream is the most preferred and also which parameter is the most chosen for the most favourite ice-cream. In table 5 it is shown the optimum result of the survey for all ice-cream types survey for organoleptic.

Based on survey, it is then given the optimum result in organoleptic test is ice-cream with $0.5 \% \mathrm{CMC}$ with the specification as follow: a very soft texture, strong fragrance, tastes very sweet with light brown colour.

Besides organoleptic test, it is also measured lce Cream Mix (ICM) in ice-cream dough made. This is to get the ice-cream overrun. The equation used is:

$\%$ Overrun $=(($ Volume Es Krim - Volume ICM $)) /$ (Volume ICM) x 100\%

Description:

$\%$ Overrun = Overrun value (\%)

Volume Ice-cream = Ice-cream volume $(\mathrm{mL})$

Volume ICM = ice-cream dough volume $(\mathrm{mL})$

By using the equation above, overrun value of each ice-cream is obtain. Table 6 shows the calculation for overrun value (attached).

From table 6 , it can be concluded that $\mathrm{CMC}$ affected the overrun, which it becomes higher.
This is of course is a positive effect to the research according to the theory mentioned in a research journal by Widiantoko, R.A, dkk (2014) which concluded that the higher the overrun value the less tough ice-cream becomes making it less prone to melting. This can happen because air is trapped in ice-cream which slow down the melting process. Hal itu terjadi karena adanya udara yang

\section{Ice-Cream Endurance Test (Melting Time)}

Determination or test of ice-cream endurance (melting time) in this research is conducted in a beaker glass with a stopwatch. In table 7 it is shown the result of the test.

\section{Syrup Production}

Main material used in the making of syrup in this research is passion fruit and sugar. In this research, syrup is made by variety $\mathrm{CMC}$ thickening agent from 1 - 3\% also it is done comparison of syrup with and without thickening agent.

In table 8 it is shown viscosity data of the syrup, begins with that without thickening agent to those with addition of CMC from 1 to $3 \%$ concentration.

From table 8, it is then known that viscosity increased with more CMC added. This is because $\mathrm{CMC}$ has got long and pretty rigid molecule

Table 8: Passion fruit viscosity

\begin{tabular}{cc}
\hline Jeais Sirup Markisah & Viskositas $(\mathbf{C P})$ \\
\hline Tanpa Penambaha CMC & 123,5 \\
CMC 1\% & 147,7 \\
CMC 2\% & 161,4 \\
CMC 3\% & 177,3 \\
\hline
\end{tabular}

Table 9: Vitamin-C content in Passion Fruit Syrup

\begin{tabular}{cc}
\hline Jeais Sirup Markisah & Viskositas $(\mathbf{C P})$ \\
\hline Tanpa Penambaha CMC & 123,5 \\
CMC 1\% & 147,7 \\
CMC 2\% & 161,4 \\
CMC 3\% & 177,3 \\
\hline
\end{tabular}


structures with negative charge from carboxyl group. Therefore $\mathrm{CMC}$ is soluble in water and form solution. $\mathrm{CMC}$ solution is very thick and stable, hence able to bind water in the syrup and maintain the bonds.

The Vitamin $C$ in the passion fruit syrup produced is shown in table 9 below.

From table 9 above, it is known that vitamin-C content is not much differ with the addition of CMC. This is because CMC can prevent vitamin-C from oxidation.

\section{CONCLUSION}

From this research it can be concluded:

1. $\alpha$-cellulose has been successfully isolated from palm oil midrib. It is then obtained 20.85 gram $\alpha$-cellulose from 75 gram palm oil midrib powder. It is estimated to be $27.80 \%$ of the initial mass of palm oil midrib powder.

2. Carboxymethyl cellulose has been successfully synthesised with isopropanol, $\mathrm{NaOh} 25 \%$ and monochloro acetate in room temperature for 2.5 hours. From 5 gram $\alpha$-cellulose powder used, given 5.86 gram CMC also 5 gram of CMC powder used in the purification process gives 4.90 gram of purer CMC.

3. Degree of substitution obtained is 0.82 which is categorised as Food Grade Accepted. Viscosity value and molecular weight obtained are $0.076 \mathrm{ml} / \mathrm{g}$ and $870.5626 \mathrm{~g} /$ mol respectively. From those numbers can be known CMC produced is low molecular weight $\mathrm{CMC}$.

4. Ice-cream can be made from milk as main ingredient with the addition of CMC as stabilizer from $\alpha$-cellulose made from palm oil midrib powder. It is known that the concentration of CMC can increase ice-cream endurance to make it last longer. Also overrun value is increased because of the $\mathrm{CMC}$ ability to make stable ice-cream. CMC can inhibit the formation of ice crystal in ice-cream and give soft structure.

5. Passion fruit syrup obtained does not undergo significant changes before and after the addition of $\mathrm{CMC}$, but viscosity was increased with the addition of $\mathrm{CMC}$ in the syrup.

\section{REFERENCES}

1. Andarwulan,N.. Kimia Vitamin, jakarta, Rajawali Press. 1992

2. Cahyana, A.S., dan Saidi, I.A.. Pengaruh

3. Jenis dan Konsentrasi Stabilizer Terhadap Karakteristik Fisik, Kimia dan Organoleptik Es Krim Bekatul. Jurnal Agrofish. 2014, 12 : 149-164.

4. COEI-1-CMC:. OIV-Oeno 366-2009 and CAS. 2009, 9004-32-4.

5. Eremeeva, T.E., and Bykova, T.O.,. SEC of mono-carboxy-methyl cellulose (CMC) in a wide range of $\mathrm{pH}$ Mark-Houwink constants. Carbohydrate Polymers, 1998, 36: 319-326.

6. Hong, K.M... Preparation and Characterization Of Carboxymethyl Cellulose From Sugarcane Bagasse. [Essay]. Malaysia: Universiti Tunku Abdul Rahman. 2013 1:21-84.

7. Ohwoavworhua, F.. Phosporic Acid-Mediated Depolymerization and Decrystallization of á-Cellulose Obtained from Corncob:
Preparation of Low Crystallinity Cellulose and Some Physicochemical Properties. Tropical Journal of Pharmaceutical Research. 2005 4(2): 509-516.

8. Padaga, M. dan Sawitri, M.E.. Es Krim Yang Sehat. Trubus Agrisarana. Surabaya. 2005.

9. Padil, Silvia, A., dan Yelmida, A.. Penentuan Temperatur Terhadap Kemurnian Selulosa-á Batang Sawit Menggunakan Ekstrak Abu TKS. Pengembangan dan Keberlanjutan Energi di Indonesia. ISBN: 2010. 978-60296729-0-9,2A07.

10. Silverio, H.A., Neto, W.P.F., Dantas, N.O., and Pasquini, D.. Extraction and Characterization of Cellulose Nanocrystals From Corncob For Application as Reinforcing Agent in Nanocomposites. Journal of Industrial Crops and Products. 2013, 44: 427-436.

11. Sundari, T. dan Saati, E.A.. Pembuatan Es Krim Lidah Buaya (Aloe Chinensis) dengan 
Penambahan Gelling Agents. 2009, 1: 89105.

12. Widiantoko, R.K., dan Yunianta.. Pembuatan Es Krim Tempe-Jahe (Kajian Proporsi Bahan dan Penstabil Terhadap Sifat Fisik,
Kimia dan Organoleptik). Jurnal Pangan dan Agroindustri. 2014, 2: 54-66.

13. Winarno, F.G.. Kimia Pangan dan Gizi. Penerbit PT Gramedia Pustaka Utama. Jakarta. 1995, 2: 34. 